\title{
INDEKS DAN TINGKAT RISIKO BAHAYA LONGSOR PADA RUAS JALAN NASIONAL DI KABUPATEN KERINCI DAN KOTA SUNGAI PENUH, PROVINSI JAMBI
}

\author{
Mutiara Sari ${ }^{1), 2)}$, Mona Foralisa Toyfur ${ }^{1)}$, dan Febrian Hadinata ${ }^{1)}$ \\ 1) Jurusan Teknik Sipil dan Perencanaan, FT UNSRI, Jl. Raya Palembang - Prabumulih Km. 32 Indralaya \\ 2) Satker Pelaksanaan Jalan Nasional Wilayah III Provinsi Sumatera Selatan
}

\begin{abstract}
The Regency of Kerinci and The City of Sungai Penuh are areas that prone to landslides. In 2021 and 2021, were 13 landslides on national road sections in both, which disrupted access to both areas. This study aims to calculate the index and determine the risk level of landslides on roads and bridges on national roads in both regions. Assessment methods and variables are taken based on the Guidelines for the Implementation of Risk Analysis for Natural Disasters Affecting Roads and Bridges. The index and risk level assessment are carried out by analyzing the risk factors for landslides, namely: hazard, exposure, vulnerability, external context, and capacity. The mapping of landslide risk based on Geographic Information Systems is based on scoring and weighting in all parameters, as well as overlays among all the constituent parameters. Based on the results of the study on ten national roads (with a total road length of $82.50 \mathrm{~km})$ in the study area into two classes, namely: (a) low class $(=8.72 \%)$ on 7 roads located within the city, and (b) medium class $(=91.28 \%)$ on three roads connecting the cities.
\end{abstract}

Key Words: Disaster risk index, Geographic Information Systems, landslides, roads and bridges.

\section{PENDAHULUAN}

Bencana adalah peristiwa yang mengancam dan mengganggu kehidupan dan penghidupan masyarakat yang disebabkan baik oleh faktor alam dan /atau faktor non alam maupun faktor manusia yang mengakibatkan timbulnya korban jiwa, kerusakan lingkungan, kerugian harta benda, dan dampak psikologis (Undang-undang Republik Indonesia Nomor 24 Tahun 2007). Longsor merupakan salah satu bentuk bencana akibat terjadinya perpindahan massa tanah pada satu waktu dengan volume yang besar. Longsor dipengaruhi oleh durasi curah hujan dan kapasitas infiltrasi, yang membuat tanah menjadi jenuh, dan menurunkan kohesi tanah (Anggraini, N., San, I. C., \& Hastuti, Y., 2016). Indonesia merupakan negara yang sering dilanda bencana longsor akibat gempa bumi dan curah hujan tinggi (Cepeda, J., Smebye, H., Vangelsten, B., Nadim, F., \& Muslim, D., 2010).

Terdapat hubungan kausal antara besarnya investasi pembangunan infrastruktur transportasi dengan peningkatan perekonomian (Aschauer, 1991). Pada negara berkembang, pertumbuhan ekonomi dipengaruhi oleh transportasi yang memadai dan dapat digunakan untuk kegiatan bisnis (Dimnwobi, S. K., Nwokoye, E. S., Ekesiobi, C. S., \& Igbanugo, C. I., 2017). Pembangunan jalan sebagai salah satu bentuk aktivitas manusia yang mempunyai pengaruh terhadap terjadinya longsor. Kegiatan pembangunan infrastruktur jalan pada suatu wilayah dapat menyebabkan terjadinya perubahan sudut lereng serta perubahan beban yang dipikul lereng disisi jalan. Frekuensi hujan yang meningkat dapat menyebabkan keruntuhan lereng, menaikkan tingkat kerusakan infrastruktur jalan rel dan jalan raya, sehingga harus dilakukan identifikasi lokasi yang berisiko mengalami keruntuhan lereng (Mori, T., Sugiyama, T., Hosooka, I., Nakata, M., Okano, K., \& Satofuka, Y. , 2019).

Kabupaten Kerinci dan Kota Sungai Penuh merupakan wilayah yang rawan bencana alam. 75 persen wilayah Kabupaten Kerinci merupakan daerah rawan bencana (BPBD_Kerinci, 2018). Saat musim hujan, sering terjadi tanah longsor di Kerinci, yang menganggu lalu lintas (jalan akses) menuju kabupaten tersebut. Kondisi geografis, geologi dan hidrologi Kabupaten Kerinci dan Kota Sungai Penuh merupakan pemicu kejadian longsor, dan bila terjadi di sekitar jaringan jalan atau jembatan, akan menimbulkan dampak negatif bagi pengguna jalan. Untuk mencegah dan meminimalkan dampak negatif akibat tanah longsor, diperlukan perencanaan dan penilaian risiko yang komprehensif (Skrzypczak, I., Kokoszka, W., Pytlowany, T., \& Radwański, W., 2020).

Akses utama menuju Kabupaten Kerinci dan Kota Sungai Penuh dari Kota Jambi adalah melalui

Attribution-NonCommercial 4.0 International. Some rights reserved 
Mutiara Sari, dkk. | Indeks dan Tingkat Resiko Bahaya Longsor Jaringan Jalan Nasional di Kabupaten Kerinci dan Kota Sungai Penuh, Provinsi Jambi Cantilever | Volume : $10 \mid$ Nomor : $01 \mid$ April $2021 \mid$ Hal. 53-61 | ISSN: 1907-4247 (Print) | ISSN: 2477-4863 (Online) | Website: http://cantilever.id

jaringan jalan nasional. Saat ini, terdapat 7 (tujuh) ruas jalan nasional yang berada di Kabupaten Kerinci dan 5 (lima) ruas jalan nasional yang berada di Kota Sungai Penuh. Pada tahun 2020 dan 2021, terdapat 13 (tiga belas) kejadian longsor pada ruas jalan nasional

tersebut

(Balai_Pelaksanaan_Jalan_Nasional_Jambi, 2021).

Longsor terjadi secara berulang pada beberapa titik, yaitu: (a) ruas jalan Sanggaran Agung - Sei Penuh sepanjang 16,77 km, yang merupakan jalur transportasi utama antara Kabupaten Kerinci dan Kota Sungai Penuh, (b) ruas jalan Sungai Penuh Siulak Deras/Letter W sepanjang 22,24 km dan, (c) ruas jalan Sungai Penuh - Bts. Prov. Sumbar sepanjang $36,30 \mathrm{~km}$ yang merupakan jalur transportasi utama yang menghubungkan kota Sungai Penuh dengan Provinsi Sumatera Barat. Ruas jalan tersebut merupakan jalan nasional (Kepmen_PUPR_No.248/KPTS/M/2015).

Sebagai acuan dalam analisis risiko bencana alam, Kementerian Pekerjaan Umum menerbitkan pedoman pelaksanaan analisis risiko bencana alam untuk jalan dan jembatan, untuk mengidentifikasi tingkat risiko jaringan jalan, dan memberikan pedoman dalam pembuatan peta risiko bencana alam untuk infrastruktur jalan dan jembatan (Kementerian_Pekerjaan_Umum, 2014). Dalam pedoman ini, penilaian menggunakan konsep indeks risiko. Penilaian risiko dilakukan untuk menentukan besaran kerusakan yang mungkin diderita jika terjadi bencana.

Oleh karena itu, diperlukan identifikasi dan analisa risiko bencana longsor yang berdampak pada jalan dan jembatan terutama pada ruas jalan nasional di Kabupaten Kerinci dan Kota Sungai Penuh berdasarkan indikator-indikator pemicu, dan selanjutnya wilayah-wilayah berpotensi bahaya tersebut akan ditampilkan dalam tabulasi dan peta risiko bencana longsor.

\section{METODOLOGI}

Penelitian ini mengacu pada pedoman (Kementerian Pekerjaan Umum, 2014) yang menggunakan konsep indeks risiko. Konsep penilaian indeks risiko yaitu penilaian dengan mengindikasikan skala ukuran atau peringkat tertentu pada risiko bencana. Setiap indikator diberikan deskripsi tertentu yang sudah ditentukan dan digambarkan dengan nilai indeks. Setiap nilai indeks indikator akan memberikan kontribusi terhadap nilai indeks risiko bencana longsor.

Data diberikan dalam bentuk nilai indeks. Nilai indeks indikator adalah pengkondisian dari setiap indikator dalam bentuk nilai tertentu yang bukan nilai sebenarnya, tetapi merupakan perbandingan karakteristik dari setiap indikator yang memiliki nilai indeks yang berbeda. Sehingga, setiap indikator yang digunakan dapat ditampilkan dalam 3 klasifikasi, yaitu: rendah, sedang dan tinggi. Kemudian dilanjutkan dengan aplikasi ArcGIS. Metodologi penelitian dapat dilihat pada Gambar 1. Penelitian dibatasi pada jalan nasional di Kabupaten Kerinci dan Kota Sungai Penuh (Tabel 1).

Faktor-faktor risiko pada penelitian ini terdiri dari: bahaya, keterpaparan, kerentanan, konteks eksternal, dan kapasitas. Masing-masing faktor risiko dinilai dengan nilai indeks indikator yang terdapat pada masing-masing faktor dan sub faktor. Masing-masing nilai indeks indikator berbanding lurus terhadap nilai indeks risiko, kecuali untuk kapasitas. Nilai indeks indikator berbanding terbalik terhadap nilai indeks risiko. Semakin baik nilai indeks indikator kapasitas, nilai indeks risiko akan lebih kecil memberikan kontribusi terhadap nilai indeks risiko. Setiap indikator akan dikalikan dengan satu nilai bobot. Nilai indeks risiko merupakan hasil penjumlahan semua nilai bobot yang dikalikan dengan nilai indeks indikator.

Dalam penelitian ini, nilai risiko dihitung sebagai nilai indeks risiko berdasarkan hasil dari penjumlahan semua nilai indeks indikator dari masing-masing faktor dan sub faktor dengan asumsi bahwa setiap indikator dianggap memiliki pengaruh yang sama besar terhadap nilai indeks risiko. Terdapat 3 (tiga) klasifikasi dari setiap indikator yang digunakan yaitu klasifikasi rendah, sedang, dan tinggi. Penilaian indeks indikator ditetapkan pada Tabel 2.

Tabel 1. Ruas Jalan Kajian

\begin{tabular}{|c|c|c|c|c|c|}
\hline No. & \multicolumn{3}{|c|}{ Nomor Ruas } & $\mathrm{Nama} \mathrm{Ru}$ a & Panjang Ruas (Km) \\
\hline 1 & 37 & & & Sanggaran Agung - Sei Penuh & 16,77 \\
\hline 2 & 37 & 11 & $\mathrm{~K}$ & Jln. Diponegoro (Sungai Penuh) & 0,25 \\
\hline 3 & 37 & 12 & $\mathrm{~K}$ & Jln. Cokroaminoto (Sungai Penuh) & 0,61 \\
\hline 4 & 37 & 13 & $\mathrm{~K}$ & Jln. M. Yamin (Sungai Penuh) & 0,58 \\
\hline 5 & 37 & 14 & K & Jln. Martadinata (Sungai Penuh) & 2,60 \\
\hline 6 & 37 & 15 & $\mathrm{~K}$ & Jln. Sultan Thaha (Sungai Penuh) & 1,70 \\
\hline 7 & 38 & & & Sungai Penuh - Bts. Prov. Sumbar & 36,3 \\
\hline 8 & 38 & 11 & $\mathrm{~K}$ & Jln. A. Yani (Sungai Penuh) & 0,33 \\
\hline 9 & 38 & 12 & $\mathrm{~K}$ & Jln. Soekarno-Hatta (Sungai Penuh) & 1,12 \\
\hline 10 & 43 & & & Sungai Penuh - Siulak Deras/Letter W & 22,24 \\
\hline & & & & UB TOTAL & 82,50 \\
\hline
\end{tabular}


Cantilever | Volume : 10 | Nomor : 01 | April 2021 | ISSN: 1907-4247 (Print) | ISSN: 2477-4863 (Online) | Website: http://cantilever.id

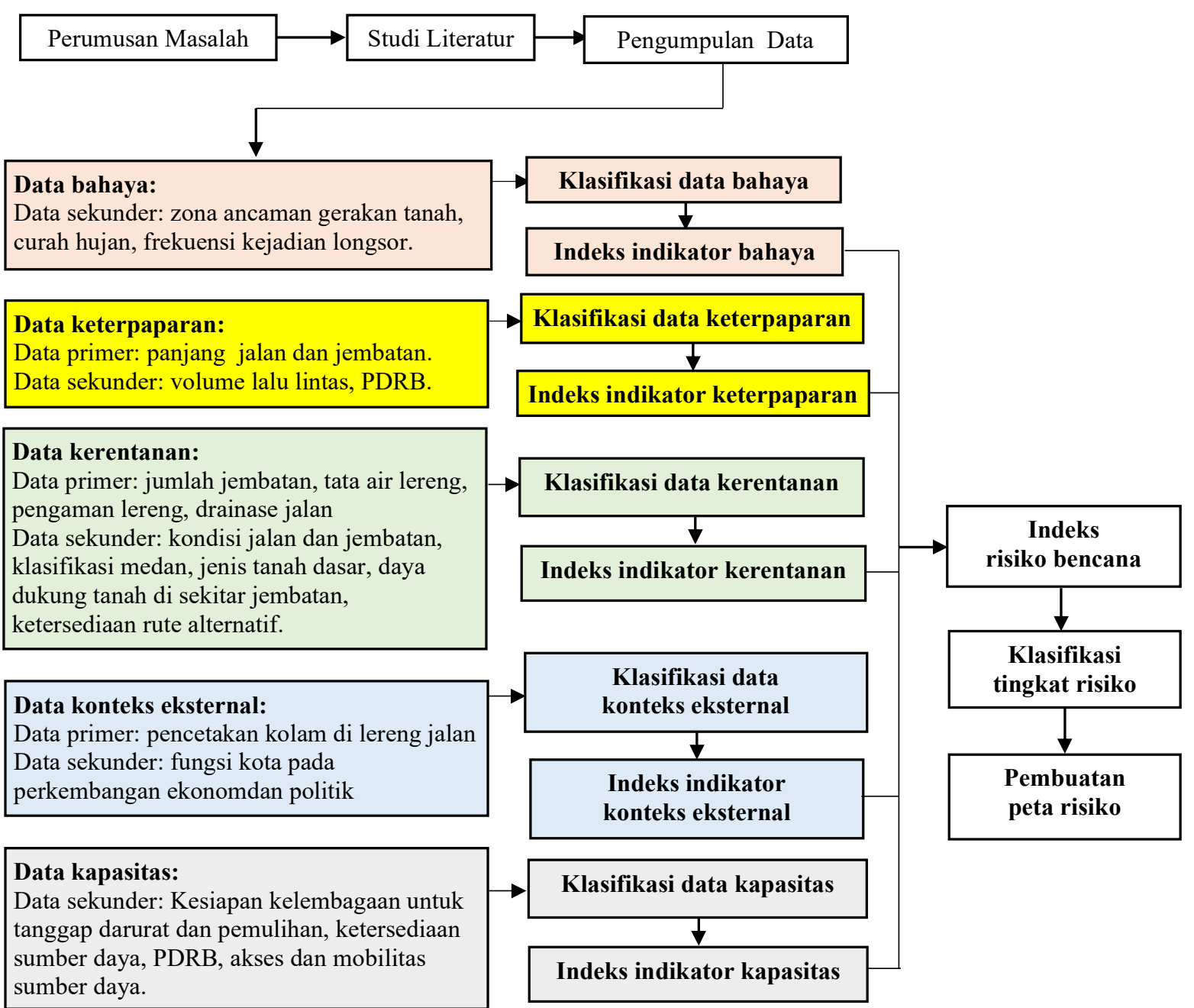

Gambar 1. Bagan alir penelitian

Tabel 2. Klasifikasi dan Nilai Indeks Indikator

\begin{tabular}{cc}
\hline Klasifikasi nilai Indikator & Nilai indeks indikator \\
\hline Rendah & 1 \\
Sedang & 2 \\
Tinggi & 3 \\
\hline
\end{tabular}

Klasifikasi nilai masing-masing indikator menggambarkan tingkat nilai indeks indikator dan kontribusinya terhadap nilai indeks risiko.

Setiap indikator memiliki kontribusi terhadap nilai indeks. Bobot dari masing-masing indikator merupakan hasil pembagian dari nilai 100\% dengan jumlah indikator dari bencana longsor (Persamaan 1).

$$
\mathbf{W}=\frac{100 \%}{\mathbf{n}}
$$

Keterangan:

$\mathrm{w}=$ Bobot indikator

$\mathrm{n}=$ Jumlah indikator

Setiap indikator dalam model indeks risiko memiliki nilai sesuai dengan kondisinya yang disebut sebagai nilai indeks indikator. Secara matematis model indeks risiko (model $\mathrm{R}$ ) terlihat dalam Persamaan 2. Metode Earthquake Disaster Risk Indeks/EDRI (Davidson, 1997).

$$
\begin{gathered}
\mathrm{Ri}=\sum W_{H i} \mathrm{Hi}+\sum W_{E i} E i+\sum W_{V i} V i+ \\
\sum W_{E x i} E x i+\sum W_{C i} C i
\end{gathered}
$$

Keterangan :

$$
\begin{array}{ll}
\mathrm{Ri} & =\text { Nilai indeks risiko bencana } \mathrm{i} \\
\mathrm{Hi} & =\text { Nilai indeks indikator bahaya } \\
\mathrm{Ei} & =\text { Nilai indeks indikator keterpaparan } \\
\mathrm{Vi} & =\text { Nilai indeks indikator kerentanan } \\
\mathrm{Exi} & =\text { Nilai indeks indikator konteks ekternal } \\
\mathrm{Ci} & =\text { Nilai indeks indikator konteks ekternal } \\
\mathrm{W} & =\text { Bobot dari masing-masing faktor } \\
\mathrm{I} & =\text { Jenis Ancaman }
\end{array}
$$

Setelah didapatkan nilai indeks maksimum dan nilai indeks risiko minimum, maka nilai indeks risiko dapat diklasifikasikan untuk mendapatkan tingkatan risiko dari nilai indeks risiko. Nilai indeks risiko maksimum dihitung dengan Persamaan 3. Sedangkan nilai indeks risiko minimum dihitung dengan Persamaan 4.

Attribution-NonCommercial 4.0 International. Some rights reserved 
Mutiara Sari, dkk. | Indeks dan Tingkat Resiko Bahaya Longsor Jaringan Jalan Nasional di Kabupaten Kerinci dan Kota Sungai Penuh, Provinsi Jambi Cantilever $\mid$ Volume : $10 \mid$ Nomor : $01 \mid$ April $2021 \mid$ Hal. 53-61 | ISSN: 1907-4247 (Print) | ISSN: 2477-4863 (Online) | Website: http://cantilever.id

$$
\begin{aligned}
& \text { Ri maks }=\mathbf{w} \times\{[(\mathbf{n}-1) \times 3)]+1\} \\
& \operatorname{Ri} \min =\mathbf{w} \times\{[(n-1) \times 1)]+3\}
\end{aligned}
$$

Keterangan:

$\operatorname{Ri} \min =$ nilai indeks risiko minimum

Ri $\max =$ nilai indeks risiko maksimum

Ri c $=$ selisih indeks risiko maksimum dan minimum
Analisis risiko yang digunakan pada penelitian ini menggunakan model indeks risiko bencana longsor. Daftar indikator dari setiap sub faktor dan faktor dari bencana longsor beserta nilai pembobotan dapat dilihat pada Tabel 3.

\begin{tabular}{|c|c|c|c|c|c|c|}
\hline FAKTOR & $\begin{array}{c}\text { Bobot A } \\
*)\end{array}$ & $\begin{array}{c}\text { SUB } \\
\text { FAKTOR }\end{array}$ & $\begin{array}{c}\text { Bobot C } \\
* *)\end{array}$ & $\begin{array}{c}\text { Kode } \\
\text { Indikator }\end{array}$ & $\begin{array}{c}\text { Bobot } \mathrm{G} \\
* * *)\end{array}$ & INDIKATOR \\
\hline $\mathbf{A}$ & B & $\mathbf{C}$ & D & $\mathbf{E}$ & $\mathbf{F}$ & $\mathbf{G}$ \\
\hline \multirow{3}{*}{ BAHAYA } & \multirow{3}{*}{12,50} & Indeks & \multirow{3}{*}{12,50} & L.1 & 4,17 & Lokasi ruas jalan pada peta zona ancaman gerakan tanah \\
\hline & & Kerentanan & & L. 2 & 4,17 & Curah hujan harian \\
\hline & & Tanah & & L. 3 & 4,17 & Frekuensi kejadian longsor di sekitar ruas jalan \\
\hline \multirow{4}{*}{$\begin{array}{l}\text { KETER- } \\
\text { PAPARAN }\end{array}$} & \multirow{4}{*}{16,67} & \multirow{2}{*}{ Fisik } & \multirow{2}{*}{8,33} & L.4 & 4,17 & Panjang ruas jalan \\
\hline & & & & L.5 & 4,17 & Panjang total jembatan \\
\hline & & Populasi & 4,17 & L. 6 & 4,17 & Volume lalu lintas \\
\hline & & Ekonomi & 4,17 & L.7 & 4,17 & PDRB Kab/Kota pada ruas jalan \\
\hline \multirow{10}{*}{ KERENTANAN } & \multirow{10}{*}{41,67} & \multirow{10}{*}{ Fisik } & \multirow{10}{*}{41,67} & L. 8 & 4,17 & Kondisi eksisting jalan \\
\hline & & & & L.9 & 4,17 & Kondisi eksisting jembatan \\
\hline & & & & L. 10 & 4,17 & Klasifikasi medan jalan \\
\hline & & & & L.11 & 4,17 & Jumlah jembatan pada ruas jalan \\
\hline & & & & L. 12 & 4,17 & Jenis tanah dasar \\
\hline & & & & L.13 & 4,17 & Daya dukung tanah disekitar jembatan \\
\hline & & & & L.14 & 4,17 & Ketersediaan rute/ruas jalan alternatif \\
\hline & & & & L. 15 & 4,17 & Tata Air Lereng \\
\hline & & & & L.16 & 4,17 & Bangunan pengaman lereng/tebing \\
\hline & & & & L.17. & 4,17 & Ketersediaan sistem drainase \\
\hline \multirow{3}{*}{$\begin{array}{c}\text { KONTEKS } \\
\text { EKSTERNAL }\end{array}$} & \multirow{3}{*}{12,50} & Ekonomi & 4,17 & KE.1 & 4,17 & Fungsi kota perkembangan ekonomi \\
\hline & & Politik & 4,17 & KE.2 & 4,17 & Fungsi kota pada politik/pemerintahan \\
\hline & & $\begin{array}{l}\text { Aktivitas } \\
\text { Manusia } \\
\end{array}$ & 4,17 & KE.3 & 4,17 & Pencetakan kolam di lereng jalan \\
\hline \multirow{4}{*}{ KAPASITAS } & \multirow{4}{*}{16,67} & Perencanaan & 4,17 & KAP.1 & 4,17 & Kesiapan kelembagaan untuk tanggap darurat dan \\
\hline & & \multirow[t]{2}{*}{ Sumber daya } & \multirow[t]{2}{*}{8,33} & KAP.2 & 4,17 & Ketersediaan sumber daya \\
\hline & & & & KAP.3 & 4,17 & PDRB Kab/Kota pada ruas jalan \\
\hline & & $\begin{array}{l}\text { Akses dan } \\
\text { Mobilitas }\end{array}$ & 4,17 & KAP.4 & 4,17 & Akses dan mobilitas sumber daya \\
\hline
\end{tabular}

Tabel 3. Daftar Indikator Bencana Longsor

Catatan:

*) : nilai bobot pada kolom B (bobot masing - masing faktor), diisi berdasarkan penjumlahan dari kolom D (bobot masing - masing sub faktornya).

**) : nilai bobot pada kolom D (bobot masing-masing sub faktor) diisi berdasarkan penjumlahan dari kolom $\mathrm{F}$ (bobot masing- masing indikatornya)

***) : nilai bobot pada kolom $\mathrm{F}$ diisi berdasarkan Persamaan 1.

Berdasarkan Tabel 2, indikator yang digunakan pada penelitian ini sebanyak 24 (dua puluh empat) indikator, dimana indikator tersebut diperoleh dari kelima faktor risiko bencana.

\subsection{Faktor Bahaya}

Zona ancaman gerakan tanah

Lokasi ruas jalan yang berada dalam zona ancaman gerakan tanah, sangat berpotensi mengalami bencana, sebab gerakan tanah menjadi salah satu faktor penting penyebab terjadinya risiko bencana longsor.
Curah hujan harian

Curah hujan harian menjadi salah satu faktor penentu karena pada saat kondisi cuaca kering akan terjadi penguapan pada tanah sehingga menimbulkan pori - pori dan rongga tanah, hingga terjadi retakan dan merekahnya tanah permukaan. Sehingga ketika hujan turun, air akan masuk melalui pori - pori dan rongga tersebut, dan terakumulasi di bagian dasar lereng, sehingga menimbulkan gerakan lateral.

\section{Frekuensi kejadian longsor di sekitar ruas jalan}

Ruas jalan yang memiliki frekuensi (historikal) kejadian longsor berulang, dapat diakibatkan oleh kondisi lingkungan yang mendukung risiko terjadinya bencana di daerah tersebut.

\subsection{Faktor Keterpaparan}

\section{Panjang ruas jalan}

Panjang ruas jalan menjadi salah satu faktor indikasi keterpaparan terhadap bencana. Semakin panjang ruas jalan, maka semakin banyak area yang memiliki kondisi lingkungan beragam. 
Cantilever | Volume : 10 | Nomor : 01 | April 2021 | ISSN: 1907-4247 (Print) | ISSN: 2477-4863 (Online) | Website: http://cantilever.id

Panjang total jembatan

Panjang total jembatan berpengaruh terhadap besarnya dampak terhadap lingkungan di sekitar jembatan, jika terjadi bencana.

Volume lalu lintas

Volume lalu lintas mempengaruhi pergerakan masyarakat. Semakin rendah volume lalu lintas, maka korban jiwa dan kerugian (bila terjadi bencana) akan semakin kecil. Volume lalu lintas juga memberikan beban tambahan pada daerah lembah, terutama pada daerah tikungan, dan sering menyebabkan terjadinya penurunan tanah dan retakan yang mengarah ke lembah.

\section{Produksi Domestik Regional Bruto (PDRB)}

Keterpaparan akan meningkat bila penghasilan bruto wilayah semakin tinggi, yang juga mengindikasikan tingginya perubahan tata guna lahan. Wilayah yang dihubungkan oleh ruas jalan maupun yang berada di sekitar ruas jalan akan terpengaruh dampak akibat bencana.

\subsection{Faktor Kerentanan}

$\underline{\text { Kondisi eksisting jalan }}$

Kondisi eksisting jalan mempengaruhi tingkat kerentanan jaringan jalan tersebut terhadap bencana longsor. Dengan kondisi jalan yang baik, arus lalu lintas dapat melalui jalan tersebut dengan cepat, nyaman, aman, dan selamat.

Kondisi eksisting jembatan pada ruas jalan

Kondisi existing jembatan mempengaruhi tingkat kerentanan suatu jaringan jalan terhadap bencana longsor. Semakin baik kondisi jembatan, maka arus lalu lintas dapat melalui jembatan tersebut dengan cepat, nyaman, aman, dan selamat.

Klasifikasi medan jalan

Klasifikasi medan jalan mempengaruhi alinyemen jalan, sehingga dapat ditentukan trase jalan pada daerah yang rawan bencana dan yang tidak rawan bencana.

Jumlah jembatan pada ruas jalan

Jumlah jembatan pada ruas jalan mempengaruhi sistem konektivitas penghubung dan mempermudah evakuasi saat terjadi bencana.

$\underline{\text { Jenis tanah dasar }}$

Jalan yang berada di area dengan kondisi tanah yang stabil, memiliki risiko terjadinya bencana yang lebih rendah dibandingkan jalan yang berada di daerah dengan tanah yang labil.
Daya dukung tanah di sekitar jembatan

Daya dukung tanah disekitar jembatan akan menentukan pengaruh penurunan pondasi dan berpengaruh erat dengan beban struktur yang akan dibangun diatasnya.

\section{Ketersedian ruas jalan alternatif}

Ketersediaan ruas jalan alternatif berperan penting dalam mengevakuasi masyarakat saat terjadi bencana, dan akses penghubung ke lokasi yang lebih aman.

\section{Tata air lereng}

Tata air lereng mempengaruhi rembesan air pada lereng, yang dapat menyebabkan penambahan tekanan air, sehingga meningkatkan terjadinya risiko bencana longsor.

\section{Pengaman lereng/tebing}

Bangunan pengaman lereng/tebing berpengaruh dalam menahan pergerakan tanah pada lereng.

\section{Ketersedian sistem drainase}

Ketersediaan sistem drainase diperlukan untuk menghindari air meresap masuk dan terkumpul pada lereng yang rawan longsor, serta berfungsi mengalirkan air limpasan hujan menjauh dari lereng yang rawan longsor.

\subsection{Konteks Eksternal}

Fungsi kota dalam perkembangan ekonomi

Fungsi kota dalam perkembangan ekonomi mempengaruhi pertumbuhan aktivitas manusia, sehingga dikhawatirkan akan berdampak pada perusakan lingkungan yang tidak terkendali.

\section{Fungsi kota dalam pemerintahan}

Fungsi kota pada politik/pemerintahan mempengaruhi pembangunan, yang dapat menambah beban pada tanah dasar, sehingga disarankan agar berada jauh dari daerah rawan bencana.

Pencetakan kolam di lereng jalan

Pencetakan kolam di lereng jalan dapat menyebabkan rembesan air kolam ke dalam lereng.

\subsection{Faktor Kapasitas}

\section{Kesiapan kelembagaan}

Kesiapan kelembagaan tanggap darurat dan pemulihan berperan penting dalam menentukan kawasan rawan bencana, memberikan masukan dan usulan kepada pemerintah daerah dalam menanggulangi lokasi-lokasi yang terdampak bencana, dan melakukakan penyelamatan serta 
Mutiara Sari, dkk. | Indeks dan Tingkat Resiko Bahaya Longsor Jaringan Jalan Nasional di Kabupaten Kerinci dan Kota Sungai Penuh, Provinsi Jambi Cantilever | Volume : $10 \mid$ Nomor : 01 | April 2021 | Hal. 53-61 | ISSN: 1907-4247 (Print) | ISSN: 2477-4863 (Online) | Website: http://cantilever.id

pertolongan korban pada daerah yang terdampak bencana sehingga tidak bertambah korban.

Ketersediaan dan kelembagaan sumber daya

Ketersediaan sumber daya dapat mempengaruhi mobilitas penduduk sehingga menyebabkan terganggunya kondisi lingkungan pada daerah yang memiliki ketersediaan sumber daya tinggi.

Produksi Domestik Regional Bruto (PDRB)

PDRB mengindikasikan bahwa keterpaparan akan meningkat bila penghasilan bruto wilayah semakin tinggi, yang juga terkait dengan indikasi besarnya perubahan tata guna lahan. Wilayah yang dihubungkan oleh ruas jalan maupun yang berada di sekitar ruas jalan akan terpengaruh dampak akibat bencana.

$\underline{\text { Akses dan mobilitas sumber daya }}$

Akses dan mobilitas sumber daya yang tinggi dapat mengganggu fungsi lindung pada daerah rawan bencana.

Penelitian yang akan dilaksanakan ini merupakan analisa deskriptif yang dipadukan dengan Sistem
Informasi Geografis (SIG), sehingga hasil penelitian yang diperoleh dapat ditampilkan dalam bentuk peta. Model indeks risiko bencana longsor pada jalan dan jembatan digunakan karena model ini menggunakan proporsi relatif dan konsep sederhana yang memudahkan pengguna untuk melakukan analisis dan mengambil keputusan.

\section{HASIL DAN PEMBAHASAN}

Setelah dilakukan pengumpulan dan klasifikasi data untuk setiap indikator, dilakukan perhitungan nilai indeks per indikator dan nilai indeks risiko bencana longsor. Model indeks risiko bencana longsor (model R) yang digunakan mengikuti Persamaan 2. Nilai dari setiap indikator merujuk pada Tabel 2 sedangkan untuk pembobotan dan kode dari setiap indikator merujuk pada Tabel 3. Indeks risiko dari setiap indikator dapat dilihat pada: (a) Tabel 4 untuk faktor bahaya, (b) Tabel 5 untuk faktor keterpaparan, (c) Tabel 6 untuk faktor kerentanan, (d) Tabel 7 untuk faktor konteks eksternal, dan (e) Tabel 8 untuk faktor kapasitas. Nilai indeks risiko bencana, yaitu penjumlahan dari setiap faktor, ditampilkan pada Tabel 10 .

Tabel 4. Indeks Risiko Bahaya Pada Ruas Jalan Nasional di Kabupaten Kerinci dan Kota Sungai Penuh

\begin{tabular}{|c|c|c|c|c|c|c|c|c|}
\hline \multirow{2}{*}{ No. } & \multirow{2}{*}{\multicolumn{3}{|c|}{ Nomor Ruas }} & \multirow{2}{*}{ Ruas Jalan } & \multicolumn{3}{|c|}{ Bahaya ( H ) } & \multirow{2}{*}{$\begin{array}{c}\text { Nilai Indeks } \\
\text { Risiko Bahaya }\end{array}$} \\
\hline & & & & & L1 & L2 & L3 & \\
\hline 1 & 37 & & & Sanggaran Agung - Sei Penuh & 1,00 & 2,00 & 2,00 & 0,21 \\
\hline 2 & 37 & 11 & $\mathrm{~K}$ & Jln. Diponegoro (Sungai Penuh) & 1,00 & 2,00 & 1,00 & 0,17 \\
\hline 3 & 37 & 12 & $\mathrm{~K}$ & Jln. Cokroaminoto (Sungai Penuh) & 1,00 & 2,00 & 1,00 & 0,17 \\
\hline 4 & 37 & 13 & $\mathrm{~K}$ & Jln. M. Yamin (Sungai Penuh) & 1,00 & 2,00 & 1,00 & 0,17 \\
\hline 5 & 37 & 14 & $\mathrm{~K}$ & Jln. Martadinata (Sungai Penuh) & 1,00 & 2,00 & 1,00 & 0,17 \\
\hline 6 & 37 & 15 & $\mathrm{~K}$ & Jln. Sultan Thaha (Sungai Penuh) & 1,00 & 2,00 & 1,00 & 0,17 \\
\hline 7 & 38 & & & Sungai Penuh - Bts. Prov. Sumbar & 3,00 & 2,00 & 3,00 & 0,33 \\
\hline 8 & 38 & 11 & $\mathrm{~K}$ & Jln. A. Yani (Sungai Penuh) & 1,00 & 2,00 & 1,00 & 0,17 \\
\hline 9 & 38 & 12 & $\mathrm{~K}$ & Jln. Soekarno-Hatta (Sungai Penuh) & 1,00 & 2,00 & 1,00 & 0,17 \\
\hline 10 & 43 & & & Sungai Penuh - Siulak Deras/Letter W & 1,00 & 2,00 & 2,00 & 0,21 \\
\hline
\end{tabular}

Tabel 5. Indeks Risiko Keterpaparan Pada Ruas Jalan Nasional di Kabupaten Kerinci dan Kota Sungai Penuh

\begin{tabular}{|c|c|c|c|c|c|c|c|c|c|}
\hline \multirow{2}{*}{ No. } & \multirow{2}{*}{\multicolumn{3}{|c|}{ Nomor Ruas }} & \multirow{2}{*}{ Ruas Jalan } & \multicolumn{4}{|c|}{ Keterpaparan ( E ) } & \multirow{2}{*}{$\begin{array}{l}\text { Indeks Risiko } \\
\text { Keterpaparan }\end{array}$} \\
\hline & & & & & L4 & L5 & L6 & L7 & \\
\hline 1 & 37 & & & Sanggaran Agung - Sei Penuh & 1,00 & 3,00 & 1,00 & 1,00 & 0,25 \\
\hline 2 & 37 & 11 & $\mathrm{~K}$ & Jln. Diponegoro (Sungai Penuh) & 1,00 & 1,00 & 1,00 & 1,00 & 0,17 \\
\hline 3 & 37 & 12 & $\mathrm{~K}$ & Jln. Cokroaminoto (Sungai Penuh) & 1,00 & 1,00 & 1,00 & 1,00 & 0,17 \\
\hline 4 & 37 & 13 & $\mathrm{~K}$ & Jln. M. Yamin (Sungai Penuh) & 1,00 & 1,00 & 1,00 & 1,00 & 0,17 \\
\hline 5 & 37 & 14 & $\mathrm{~K}$ & Jln. Martadinata (Sungai Penuh) & 1,00 & 1,00 & 1,00 & 1,00 & 0,17 \\
\hline 6 & 37 & 15 & $\mathrm{~K}$ & Jln. Sultan Thaha (Sungai Penuh) & 1,00 & 1,00 & 1,00 & 1,00 & 0,17 \\
\hline 7 & 38 & & & Sungai Penuh - Bts. Prov. Sumbar & 2,00 & 3,00 & 1,00 & 1,00 & 0,29 \\
\hline 8 & 38 & 11 & $\mathrm{~K}$ & Jln. A. Yani (Sungai Penuh) & 1,00 & 1,00 & 1,00 & 1,00 & 0,17 \\
\hline 9 & 38 & 12 & $\mathrm{~K}$ & Jln. Soekarno-Hatta (Sungai Penuh) & 1,00 & 1,00 & 1,00 & 1,00 & 0,17 \\
\hline 10 & 43 & & & Sungai Penuh - Siulak Deras/Letter W & 2,00 & 3,00 & 1,00 & 1,00 & 0,29 \\
\hline
\end{tabular}


Cantilever | Volume : 10 | Nomor : 01 | April 2021 | ISSN: 1907-4247 (Print) | ISSN: 2477-4863 (Online) | Website: http://cantilever.id

Tabel 6. Indeks Risiko Kerentanan pada Ruas Jalan Nasional di Kabupaten Kerinci dan Kota Sungai Penuh

\begin{tabular}{|c|c|c|c|c|c|c|c|c|c|c|c|c|c|}
\hline \multirow{2}{*}{ No. } & \multirow{2}{*}{\multicolumn{2}{|c|}{$\begin{array}{c}\text { Nomor } \\
\text { Ruas }\end{array}$}} & \multirow{2}{*}{ Ruas Jalan } & \multicolumn{9}{|c|}{ Kerentanan ( V) } & \multirow{2}{*}{$\begin{array}{c}\text { Indeks Risiko } \\
\text { Kerentanan }\end{array}$} \\
\hline & & & & L8 & L9 & L10 L11 & L12 & L13 & L14 & L15 & L16 & L17 & \\
\hline 1 & 37 & & Sanggaran Agung - Sei Penuh & 1,00 & 1,00 & $1,003,00$ & 2,00 & 2,00 & 3,00 & 2,00 & 3,00 & 3,00 & 0,88 \\
\hline 2 & 37 & $11 \mathrm{~K}$ & Jln. Diponegoro (Sungai Penuh) & 1,00 & 1,00 & $1,001,00$ & 1,00 & 1,00 & 1,00 & 1,00 & 1,00 & 1,00 & 0,42 \\
\hline 3 & 37 & $12 \mathrm{~K}$ & Jln. Cokroaminoto (Sungai Penuh) & 1,00 & 1,00 & $1,001,00$ & 1,00 & 1,00 & 1,00 & 1,00 & 1,00 & 1,00 & 0,42 \\
\hline 4 & 37 & $13 \mathrm{~K}$ & Jln. M. Yamin (Sungai Penuh) & 1,00 & 1,00 & $1,001,00$ & 1,00 & 1,00 & 1,00 & 1,00 & 1,00 & 1,00 & 0,42 \\
\hline 5 & 37 & $14 \mathrm{~K}$ & Jln. Martadinata (Sungai Penuh) & 1,00 & 1,00 & $1,001,00$ & 1,00 & 1,00 & 1,00 & 1,00 & 1,00 & 1,00 & 0,42 \\
\hline 6 & 37 & $15 \mathrm{~K}$ & Jln. Sultan Thaha (Sungai Penuh) & 1,00 & 1,00 & $1,001,00$ & 1,00 & 1,00 & 1,00 & 1,00 & 1,00 & 1,00 & 0,42 \\
\hline 7 & 38 & & Sungai Penuh - Bts. Prov. Sumbar & 1,00 & 1,00 & $3,003,00$ & 2,00 & 2,00 & 3,00 & 2,00 & 3,00 & 3,00 & 0,96 \\
\hline 8 & 38 & $11 \mathrm{~K}$ & Jln. A. Yani (Sungai Penuh) & 1,00 & 1,00 & $1,001,00$ & 1,00 & 1,00 & 1,00 & 1,00 & 1,00 & 1,00 & 0,42 \\
\hline 9 & 38 & $12 \mathrm{~K}$ & Jln. Soekarno-Hatta (Sungai Penuh) & 1,00 & 1,00 & $1,001,00$ & 1,00 & 1,00 & 1,00 & 1,00 & 1,00 & 1,00 & 0,42 \\
\hline 10 & 43 & & Sungai Penuh - Siulak Deras/Letter W & 1,00 & 1,00 & $1,003,00$ & 2,00 & 2,00 & 3,00 & 2,00 & 3,00 & 3,00 & 0,88 \\
\hline
\end{tabular}

Tabel 7. Indeks Risiko Konteks Eksternal Pada Ruas Jalan Nasional di Kabupaten Kerinci dan Kota Sungai Penuh

\begin{tabular}{|c|c|c|c|c|c|c|c|c|}
\hline \multirow{2}{*}{ No. } & \multirow{2}{*}{\multicolumn{3}{|c|}{ Nomor Ruas }} & \multirow{2}{*}{ Ruas Jalan } & \multicolumn{3}{|c|}{ Konteks Eksternal ( Ex ) } & \multirow{2}{*}{$\begin{array}{c}\text { Indeks Risiko } \\
\text { Konteks Eksternal }\end{array}$} \\
\hline & & & & & KE1 & KE2 & KE3 & \\
\hline 1 & 37 & & & Sanggaran Agung - Sei Penuh & 2,00 & 2,00 & 1,00 & 0,21 \\
\hline 2 & 37 & 11 & $\mathrm{~K}$ & Jln. Diponegoro (Sungai Penuh) & 2,00 & 2,00 & 1,00 & 0,21 \\
\hline 3 & 37 & 12 & $\mathrm{~K}$ & Jln. Cokroaminoto (Sungai Penuh) & 2,00 & 2,00 & 1,00 & 0,21 \\
\hline 4 & 37 & 13 & $\mathrm{~K}$ & Jln. M. Yamin (Sungai Penuh) & 2,00 & 2,00 & 1,00 & 0,21 \\
\hline 5 & 37 & 14 & $\mathrm{~K}$ & Jln. Martadinata (Sungai Penuh) & 2,00 & 2,00 & 1,00 & 0,21 \\
\hline 6 & 37 & 15 & $\mathrm{~K}$ & Jln. Sultan Thaha (Sungai Penuh) & 2,00 & 2,00 & 1,00 & 0,21 \\
\hline 7 & 38 & & & Sungai Penuh - Bts. Prov. Sumbar & 2,00 & 2,00 & 1,00 & 0,21 \\
\hline 8 & 38 & 11 & $\mathrm{~K}$ & Jln. A. Yani (Sungai Penuh) & 2,00 & 2,00 & 1,00 & 0,21 \\
\hline 9 & 38 & 12 & $\mathrm{~K}$ & Jln. Soekarno-Hatta (Sungai Penuh) & 2,00 & 2,00 & 1,00 & 0,21 \\
\hline 10 & 43 & & & Sungai Penuh - Siulak Deras/Letter W & 2,00 & 2,00 & 1,00 & 0,21 \\
\hline
\end{tabular}

Tabel 8. Nilai Indeks Risiko Kapasitas Pada Ruas Jalan Nasional di Kabupaten Kerinci dan Kota Sungai Penuh

\begin{tabular}{|c|c|c|c|c|c|c|c|c|c|}
\hline \multirow{2}{*}{ No. } & \multirow{2}{*}{\multicolumn{3}{|c|}{ Nomor Ruas }} & \multirow{2}{*}{ Ruas Jalan } & \multicolumn{4}{|c|}{ Kapasitas ( C ) } & \multirow{2}{*}{$\begin{array}{c}\text { Indeks Risiko } \\
\text { Kapasitas }\end{array}$} \\
\hline & & & & & KAP1 & KAP2 & KAP3 & KAP4 & \\
\hline 1 & 37 & & & Sanggaran Agung - Sei Penuh & 2,00 & 2,00 & 3,00 & 1,00 & 0,33 \\
\hline 2 & 37 & 11 & $\mathrm{~K}$ & Jln. Diponegoro (Sungai Penuh) & 2,00 & 2,00 & 3,00 & 1,00 & 0,33 \\
\hline 3 & 37 & 12 & $\mathrm{~K}$ & Jln. Cokroaminoto (Sungai Penuh) & 2,00 & 2,00 & 3,00 & 1,00 & 0,33 \\
\hline 4 & 37 & 13 & $\mathrm{~K}$ & Jln. M. Yamin (Sungai Penuh) & 2,00 & 2,00 & 3,00 & 1,00 & 0,33 \\
\hline 5 & 37 & 14 & $\mathrm{~K}$ & Jln. Martadinata (Sungai Penuh) & 2,00 & 2,00 & 3,00 & 1,00 & 0,33 \\
\hline 6 & 37 & 15 & $\mathrm{~K}$ & Jln. Sultan Thaha (Sungai Penuh) & 2,00 & 2,00 & 3,00 & 1,00 & 0,33 \\
\hline 7 & 38 & & & Sungai Penuh - Bts. Prov. Sumbar & 2,00 & 2,00 & 3,00 & 1,00 & 0,33 \\
\hline 8 & 38 & 11 & $\mathrm{~K}$ & Jln. A. Yani (Sungai Penuh) & 2,00 & 2,00 & 3,00 & 1,00 & 0,33 \\
\hline 9 & 38 & 12 & $\mathrm{~K}$ & Jln. Soekarno-Hatta (Sungai Penuh) & 2,00 & 2,00 & 3,00 & 1,00 & 0,33 \\
\hline 10 & 43 & & & Sungai Penuh - Siulak Deras/Letter W & 2,00 & 2,00 & 3,00 & 1,00 & 0,33 \\
\hline
\end{tabular}

Berdasarkan Tabel 4, 5, 6, 7 dan 8, didapat nilai untuk setiap indeks risiko pada masing-masing faktor, yaitu:

(a) Faktor bahaya yang terdiri dari tiga indikator, dengan indeks risiko terendah pada tujuh ruas jalan di dalam kota, dan nilai indeks risiko tertinggi pada ruas jalan Sungai Penuh - Bts Prov. Sumbar, karena pada ruas ini, indeks pada indikator zona ancaman gerakan tanah dan frekuensi kejadian longsor mempunyai nilai 3 (tinggi),

(b) Faktor keterpaparan yang terdiri dari empat indikator, dengan indeks risiko terendah pada tujuh ruas jalan di dalam kota, dan nilai indeks risiko tertinggi pada dua ruas jalan penghubung antar kota, yaitu: ruas jalan Sungai Penuh - Bts Prov. Sumbar dan Sungai Penuh - Siulak Deras/Letter W. Pada kedua ruas ini, nilai indeks pada indikator panjang ruas jalan mempunyai nilai 2 (sedang), dan pada indikator panjang total jembatan mempunyai nilai 3 (tinggi),

(c) Faktor kerentanan yang terdiri dari sepuluh indikator, dengan indeks risiko terendah pada tujuh ruas jalan di dalam kota, dan indeks risiko tinggi berada pada ruas jalan penghubung antar kota, yaitu: Sanggaran Agung - Sei Penuh, Sungai Penuh - Bts Prov. Sumbar, dan Sungai Penuh - Siulak Deras/Letter W. Pada ketiga ruas jalan ini, indeks indikator pada jumlah jembatan, ketersediaan rute alternatif, bangunan pengaman tebing dan ketersediaan sistem drainase mempunyai nilai 3 (tinggi). Indikator klasifikasi medan jalan juga mempunyai nilai tinggi, tetapi hanya untuk ruas jalan Sungai Penuh - Bts. Prov. Sumbar,

(d) Faktor konteks eksternal terdiri dari tiga indikator, dan 
Mutiara Sari, dkk. | Indeks dan Tingkat Resiko Bahaya Longsor Jaringan Jalan Nasional di Kabupaten Kerinci dan Kota Sungai Penuh, Provinsi Jambi Cantilever $\mid$ Volume : $10 \mid$ Nomor : $01 \mid$ April $2021 \mid$ Hal. 53-61 | ISSN: 1907-4247 (Print) $\mid$ ISSN: 2477-4863 (Online) | Website: http://cantilever.id

(e) Faktor kapasitas terdiri dari empat indikator, dimana semua ruas jalan mempunyai indeks risiko yang sama besar di masing - masing indikator. Indikator PDRB pada faktor kapasitas mempunyai nilai 3 (tinggi) pada semua ruas jalan.

Berdasarkan penjumlahan nilai indeks risiko dari setiap faktor, maka ditentukan nilai batas untuk setiap tingkat risiko (Tabel 9) dan nilai indeks risiko bencana longsor $(\mathrm{R})$ yang dapat dilihat pada Tabel 10.

Tabel 9. Nilai Batas Untuk Setiap Tingkat Risiko

\begin{tabular}{cc}
\hline Risiko & Nilai Batas Atas dan Bawah \\
\hline R rendah & $1,08-1,69$ \\
R sedang & $1,69-2,31$ \\
R tinggi & $2,31-2,92$ \\
\hline
\end{tabular}

Tabel 10. Nilai Indeks Risiko Bencana Pada Ruas Jalan Nasional di Kabupaten Kerinci dan Kota Sungai Penuh

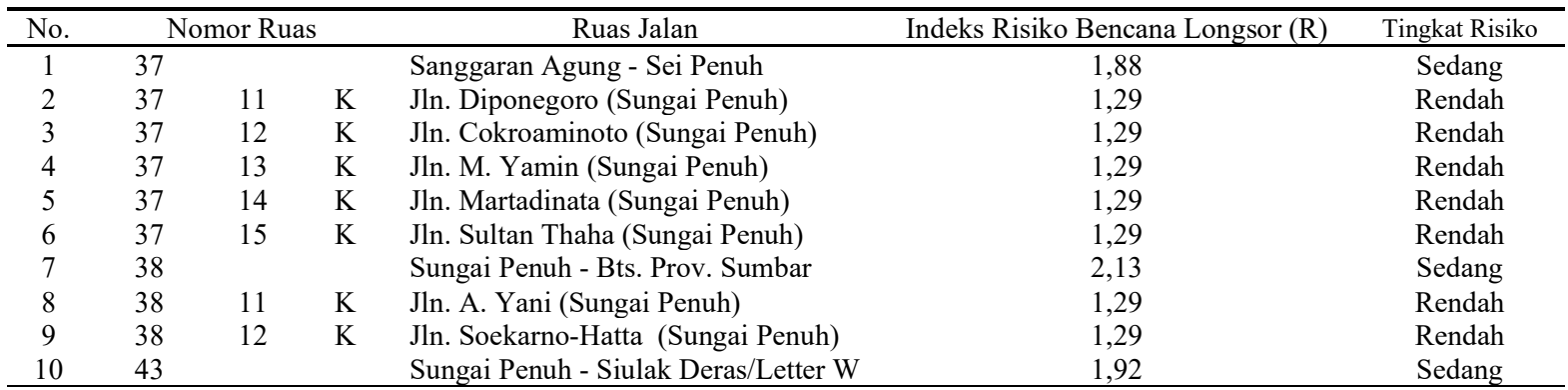

Berdasarkan Tabel 10, diketahui nilai indeks risiko bencana longsor $(\mathrm{R})$ pada seluruh ruas jalan yang di tinjau. Terdapat tiga ruas jalan penghubung antar kota termasuk dalam klasifikasi sedang, yaitu: Sanggaran Agung - Sei Penuh, Sungai Penuh - Bts. Prov. Sumbar dan Sungai Penuh - Siulak Deras/Letter W. Sedangkan tujuh ruas jalan lainnya yang berada di dalam kota masuk kedalam klasifikasi rendah dengan rata-rata panjang ruas jalan yang pendek antara $0,25 \mathrm{~km}$ sampai $2,60 \mathrm{~km}$, yaitu ruas Jln. Diponegoro, Jln. Cokroaminoto, Jln. M. Yamin, Jln. Martadinata, Jln. Sultan Thaha, Jln. A. Yani, Jln. Soekarno-Hatta.

Berdasarkan hasil analisa, diketahui bahwa $8,72 \%$ ruas jalan $(=7,19 \mathrm{~km})$ memiliki tingkat risiko rendah, dan $91,28 \%(=75,31 \mathrm{~km})$ berada pada tingkat risiko sedang. Tidak ada ruas jalan nasional di Kota Sungai Penuh dan Kababupaten Kerinci yang memiliki tingkat risiko tinggi (Tabel 11).

Table 11. Klasifikasi dan Nilai Indeks Risiko Bencana Longsor

\begin{tabular}{ccc}
\hline Tingkat risiko & Panjang $(\mathrm{Km})$ & Persentase $(\%)$ \\
\hline Rendah & 7,19 & 8,72 \\
Sedang & 75,31 & 91,28 \\
Tinggi & - & - \\
\hline
\end{tabular}

Sistem Informasi Geografis digunakan untuk menumpangsusunkan berbagai indikator penyebab longsor pada ruas jalan ini. Peta Indeks Risiko dibangun dengan menggunakan Analisa Spasial Overlay - Intersect dari setiap faktor (Gambar 2).

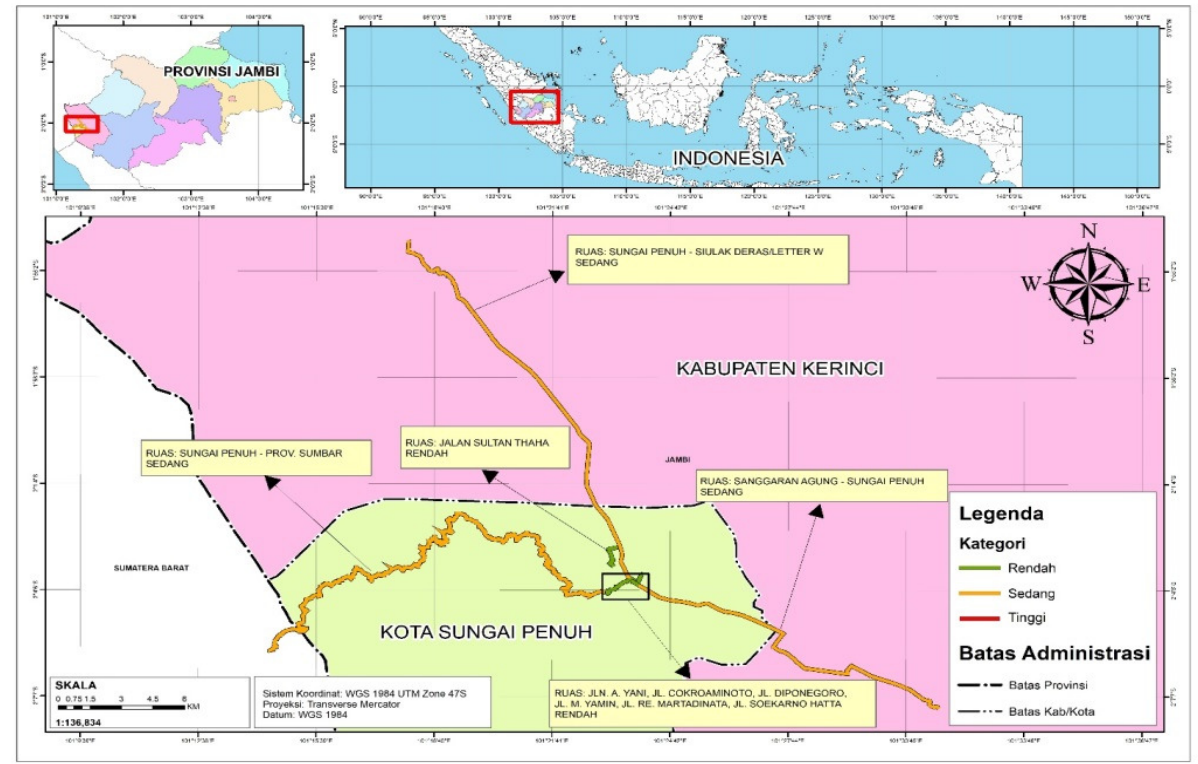

Gambar 2. Peta Indeks Risiko Longsor pada Ruas Jalan Nasional Kabupaten Kerinci dan Kota Sungai Penuh 
Cantilever | Volume : 10 | Nomor : 01 | April 2021 | ISSN: 1907-4247 (Print) | ISSN: 2477-4863 (Online) | Website: http://cantilever.id

\section{KESIMPULAN}

Indeks bahaya longsor di Kota Sungai Penuh dan Kabupaten Kerinci diklasifikasikan dalam kelas rendah dan sedang. Tujuh ruas jalan termasuk dalam klasifikasi rendah yaitu ruas Jln. Diponegoro, Jln. Cokroaminoto, Jln. M. Yamin, Jln. Martadinata, Jln. Sultan Thaha, Jln. A. Yani, Jln. Soekarno-Hatta. Tiga ruas jalan lainnya termasuk dalam klasifikasi sedang, yaitu: Sanggaran Agung - Sei Penuh, Sungai Penuh - Bts. Prov. Sumbar dan Sungai Penuh Siulak Deras/Letter W.

Walaupun frekuensi kejadian longsor di ruas jalan Sungai Penuh - Bts. Prov. Sumbar termasuk dalam kelas tinggi, tetapi hanya diklasifikasikan dalam indeks bahaya sedang. Hal ini membutuhkan kajian lebih lanjut terkait metode penilaian indeks resiko bahaya longsor di ruas jalan, terutama terkait pembobotan untuk setiap variabel.

Tingkat risiko bahaya longsor pada ruas jalan kajian berdasarkan tingkat risiko bahaya, keterpaparan, kerentanan, konteks ekternal dan kapasitas pengelola jalan terbagi menjadi dua klasifikasi, yaitu: klasifikasi rendah sepanjang $7,19 \mathrm{~km}(8,72 \%)$ dan klasifikasi sedang sepanjang 75,31 km (91,28 \%).

\section{UCAPAN TERIMA KASIH}

Terima kasih saya ucapkan kepada Balai Pelaksanaan Jalan Nasional Jambi yang telah mendukung penyediaan data dalam kajian ini.

\section{REFERENSI}

Anggraini, N., San, I. C., \& Hastuti, Y. (2016). Analisa Dampak Perubahan Iklimterhadap Kelongsoran dengan Mengestimasi Penurunan Nilai Kohesivitas Tanah. Cantilever: Jurnal Penelitian dan Kajian Bidang Teknik Sipil, 5(2), 25-30.

Aschauer, A. (1991). Transportation Spending and Economic Growth. Washington DC: American Public Transit Association

Balai_Pelaksanaan_Jalan_Nasional_Jambi. (2021). Rekapitulasi Lokasi Longsor di Provinsi Jambi. Jambi.

BPBD_Kerinci. (2018). 75 Percent of Kerinci Area is Disaster Prone. Retrieved August 26, 2020, from http://metrojambi.com/read/2018/11/19/37419/75persen-wilayah-kerinci-rawan-bencana.html

Cepeda, J., Smebye, H., Vangelsten, B., Nadim, F., \& Muslim, D. (2010). Landslide risk in Indonesia. Jakarta: ISDR.

Davidson, R. (1997). An Urban Earthquake Disaster Risk Index. California: The John A. Blume Earthquake Engineering Centre.

Dimnwobi, S. K., Nwokoye, E. S., Ekesiobi, C. S., \& Igbanugo, C. I. (2017). Transportation infrastructure and diversification of Nigeria's economy: implications for the developmental state. The Nigerian journal of economic and social studies, 59(3), 309-330.

Kementerian_Pekerjaan_Umum. (2014). Pedoman dan Petunjuk Pelaksanaan Analisis Risiko Bencana Alam Yang Berdampak Pada Jalan dan Jembatan. Jakarta.

Kepmen_PUPR_No.248/KPTS/M/2015. (t.thn.). Penetapan Ruas Jalan Dalam Jaringan Jalan Primer Menurut Fungsi Sebagai Jalan Arteri (JAP) dan Jalan Kolektor-1 (JKP-1). Jakarta.

Mori, T., Sugiyama, T., Hosooka, I., Nakata, M., Okano, K., \& Satofuka, Y. . (2019). Slope Failure Risk Assessment Modeling Using Topographic Data and Numerical Calculation of Soil Conservation by Tree Root Systems. ISPRS Annals of the Photogrammetry, Remote Sensing and Spatial Information Sciences, Volume $I V-2 / W 5$ (pp. 217-222). Netherlands: Enschede.

Skrzypczak, I., Kokoszka, W., Pytlowany, T., \& Radwański, W. (2020). Landslides and the risk of damage to road infrastructure on the example of a transport node. Nodes in Transport Networks - Research, Data Analysis and Modelling (pp. 53-62). Katowice, Poland: Springer.

Undang-undang Republik Indonesia Nomor 24 Tahun 2007. (n.d.). 